Kinestetik : Jurnal Ilmiah Pendidikan Jasmani 5 (3) (2021)

Kinestetik : Jurnal Ilmiah Pendidikan Jasmani

https://ejournal.unib.ac.id/index.php/kinestetik/index

DOI : 10.33369/jk.v5i3.17327

\title{
ANALYSIS STRENGTH AND ENDURANCE OF NEW STUDENTS SPORTS EDUCATION FACULTY IN TEACHER TRAINING AND EDUCATION MUHAMMADIYAH UNIVERSITY OF SURAKARTA
}

\section{Nurhidayat $^{1 *}$, Eko Sudarmanto ${ }^{2}$, Gatot Jariono $^{3}$, Ardhian Tomy Kurniawan ${ }^{4}$, Fathurrahman 5}

1,2,3,4,5 Sports Education, Teacher Training and Education Faculty, Universitas Muhammadiyah Surakarta, Surakarta, Indonesia

\begin{tabular}{l} 
Article Info \\
\hline Article History : \\
Received :August 2021 \\
Revised : September 2021 \\
Accepted : September 2021 \\
Available online : September \\
2021
\end{tabular}

Keywords:

Endurance, Student, Strength

\begin{abstract}
The purpose of this study is to analyze the strength and endurance of new students of FKIP sports education at The University of Muhammadiyah Surakarta in 2020 which includes arm muscle strength, abdominal muscle strength, and maximum oxygen volume ability (VO2max). This research is descriptive research using the closeness of quantitative research types. The sample in this study is all new students of FKIP UMS sports education in 2020 numbered 141 people. Teknik collection uses push-up tests to measure arm muscle strength, sit-up tests to measure abdominal muscle strength, and MFT (multistage fitness test) running tests. Teknik data analysis uses frequency descriptive analysis with the help of excel 2019 Microsoft software. The results of this study can be concluded: (i) the strength of new students POR FKIP as a whole is a moderate category obtained from the push-up test with a percentage of $36.88 \%$; (ii) sit up tests with a percentage of $36.17 \%$, and (iii) endurance freshmen POR UMS category good category with a percentage of $34.75 \%$. But in this study, it is necessary to pay attention to the quality of other physical conditions, namely flexibility, agility, speed, and psychology of students and those related in this study on physical tests and sports ability.
\end{abstract}

Corresponding address : Jl. Ahmad Yani Tromol Pos 1 Pabelan

Surakarta Jawa Tengah Indonesia

*Corresponding email: nur574@ums.ac.id
ISSN 2685-6514 (Online)

ISSN 2477-331X (Print) 


\section{INTRODUCTION}

FKIP sports education study program Muhammadiyah University of Surakarta by general provides practical courses. As a new student of the FKIP UMS Sports Education study program, having a good physical condition is very important, so that the process of attending lectures and activities in the village can run optimally. To carry out activities as a student, it takes good physical condition so that all activities undertaken can be carried out optimally, both activities in the village and activities outside the campus.

In general, activities in sports activities are repetitive movements with varying intensity and duration. Physical activity is a daily activity that a person does to maintain body fitness. This is in line with the opinions (Mansur et al., 2018); Irianto (2000), Faturrohman and Sutikno (2020), (Winardi, 2016); Winardi (2007), (Ratnasari, 2017); Rivai and Murni (2009) someone who performs the physical activity with the type of exercise and intensity that has been qualified, as well as the length of exercise with sufficient frequency every week, will be able to obtain and maintain physical fitness. Physical fitness is doing daily activities without feeling meaningful fatigue. This is in line with some of the results of Mutohir and Maksum (2007), Mukholid (2007), Wahjoedi (2003), Ministry of Health (2009), and Giriwijoyo (2007) some experts argue that physical fitness is a very important aspect of overall physical fitness, which will give a person the ability to live a productive life and be able to adjust to every proper physical burden.

To obtain a good status or level of physical fitness can even be classified in the prime category, a student is required to do regular and programmatic physical exercise (Fachrezzy et al., 2020; Hermawan et al., 2020, 2021; Jariono et al., 2001, 2020; Jariono \& Subekti, 2020; Nugroho et al., 2021). Physical exercise is closely related to maintaining a physical condition that is necessary for someone who wants to maintain and improve physical fitness. Good physical fitness can be improved by paying attention to the factors needed for the activity such as endurance, strength, speed, and flexibility. Therefore, physical activity is necessary to improve and develop physical fitness. Physical fitness or often called physical fitness is a person's ability to do daily tasks and work vigorously and alertly without experiencing significant fatigue, and still have energy reserves to fill free time and face unexpected emergencies before (Hadi, 2007).

Strength is a component of a person's physical condition about his ability to use muscles to receive weights while working optimally (Nuril Ahmadi, 2007). According to Hardiansyah (2017) strength is the ability of muscles in holding or receiving burdens in carrying out work. Strength is one of the important components to support physical activity, especially in exercise. According to Sajoto (1988) stated: "strength or strength is a component of physical condition that concerns the ability of an athlete when using his muscles, receiving burdens in a certain work time". Based on the above opinion it can be concluded that strength is the strength of a muscle or a group of muscles to fight and hold weights when doing certain jobs. In addition, the power can be seen from the ability of the individual to attract, push, press an object while the body is in a resting position. The strength or strength that is the focus of this study is arm muscle strength and abdominal muscle strength.

To find out the level of physical fitness or endurance a person can be seen from several indicators. Indicators of a person's level of physical fitness are a 
person's ability or capacity to use as much oxygen as they can (Maximum Aerobic Capacity / VO2 max). One important way to determine cardiovascular freshness is to measure the magnitude of $\mathrm{VO} 2$ max. Based on the above description, the researcher intends to conduct a strength and endurance analysis of new students of FKIP UMS Sports Education in 2020.

\section{METHODS}

Research methods can be interpreted as procedures or ways taken to achieve research goals. This study uses survey research using a quantitative descriptive approach.

\section{Participants}

The population and research sample of all new students of FKIP UMS Sports Education in 2020 amounted to 141 students.

\section{Sampling Procedures}

The sampling technique in this study is total sampling. Total sampling is a sampling technique where the number of samples is equal to the population (Sugiyono, 2007). The sample taken from the study was 141 students.

\section{Materials and Apparatus}

The data collection technique used in this study is with test and measurement techniques to obtain data on the specific physical condition of POR FKIP UMS freshmen. The tests used are a 60-second push-up test to measure arm muscle strength, a 60-second sit-up test to measure abdominal muscle strength, and an MFT (Multistage Fitness Test) to measure maximum oxygen volume (VO2max) ability.

\section{Procedures}

The analytical techniques in this study use quantitative descriptive statistical analysis then processed into percentage form. According to Riduwan (2019)," for research that uses quantitative approaches, this data analysis technique is concerned to answer the formulation of the proposed problem" (Riduwan, 2019). Before doing statistical analysis, first, categorize strength and endurance as in the table as follows.

Table 1. Group Categorization Table

\begin{tabular}{llc}
\hline No. & Category & Normal Range \\
\hline 1 & Very Good & $\mathrm{X} \geq \mathrm{M}+1.5 \mathrm{SD}$ \\
\hline 2 & Good & $\mathrm{M}+0.5 \mathrm{SD} \leq \mathrm{X}<\mathrm{M}+1.5 \mathrm{SD}$ \\
\hline 3 & Medium & $\mathrm{M}-0.5 \mathrm{SD} \leq \mathrm{X}<\mathrm{M}+0.5 \mathrm{SD}$ \\
\hline 4 & Less & $\mathrm{M}-1.5 \mathrm{SD} \leq \mathrm{X}<\mathrm{M}-0.5 \mathrm{SD}$ \\
\hline 5 & Less Once & $\mathrm{X}<\mathrm{M}-1.5 \mathrm{SD}$ \\
\hline Information: & \\
M: Mean \\
SD: Standard Deviation \\
(Azwar 2011, p.148)
\end{tabular}

After categorizing strength and endurance data, then a quantitative descriptive statistical analysis is carried out that is processed into percentage form. As for knowing the percentage according to Sudijono (2012) is to use the following formula:

Information:

$$
\mathrm{P}=\frac{\mathrm{F}}{\mathrm{N}} \mathrm{X} 100 \%
$$

$\mathrm{F}$ : The frequency that is being sought a percentage

$\mathrm{N}$ : The number of frequencies/ number of individuals

Q: Percentage number

(Sudijono, 2012)

\section{Design or Data Analysis}

The data analysis used in this study is a percentage descriptive analysis. Overall for data analysis using Microsoft Excel 2019 software. 


\section{RESULTS}

\section{Strength}

Here is the strength test data in 5 categories of groups, namely very good, good, medium, less, and less once in the table below:

Table 2. Frequency Distribution Strength of Push Up test results

\begin{tabular}{llc}
\hline No. & Category & Percentage \\
\hline 1 & Very Good & $8,51 \%$ \\
\hline 2 & Good & $24,82 \%$ \\
\hline 3 & Medium & $36,88 \%$ \\
\hline 4 & Less & $24,82 \%$ \\
\hline 5 & Less Once & $4,96 \%$ \\
\hline
\end{tabular}

Based on the table above that the endurance of new students of sports education FKIP UMS as many as 8 students $(5.67 \%)$ thanks to good categories, 49 students $(34.75 \%)$ good categories, 38 students $(26.95 \%)$ quite categories, 37 (26.24\%) fewer categories, and 9 students $(6.38 \%)$ said less at all. The most frequency lies in the medium category, thus the strength of the moderate category.

Table 3. Frequency Distribution Strength test results Sit Up

\begin{tabular}{clc}
\hline No. & Category & Percentage \\
\hline 1 & Very Good & $4,96 \%$ \\
\hline 2 & Good & $22,70 \%$ \\
\hline 3 & Medium & $36,17 \%$ \\
\hline 4 & Less & $26,95 \%$ \\
\hline 5 & Less Once & $9,22 \%$ \\
\hline
\end{tabular}

Based on the table above that the endurance of new students of sports education FKIP UMS as many as 7 students $(4.97 \%)$ thanks to good categories, 32 students $(22.70 \%)$ blessings well, 51 students $(36.17 \%)$ quite categories, 38 (26.95\%) fewer categories, and 13 students $(9.22 \%)$ said less at all. The most frequency lies in the medium category, thus the strength of the moderate category.

2. Endurance

Here is the endurance data spelled out in 5 group categories, namely very good, good, medium, less, and less once in the table below:

Table 4. Endurance Frequency

Distribution of MFT test results

\begin{tabular}{llc}
\hline No. & Category & Percentage \\
\hline 1 & Very Good & $5,67 \%$ \\
\hline 2 & Good & $34,75 \%$ \\
\hline 3 & Medium & $26,95 \%$ \\
\hline 4 & Less & $26,24 \%$ \\
\hline 5 & Less Once & $6,38 \%$ \\
\hline
\end{tabular}

Based on the table above that the endurance of new students of sports education FKIP UMS as many as 8 students $(5.67 \%)$ thanks to good categories, 49 students $(34.75 \%)$ good categories, 38 students $(26.95 \%)$ quite categories, 37 (26.24\%) fewer categories, and 9 students $(6.38 \%)$ said less at all. The most frequency lies in the good category, thus the endurance of the good category.

\section{DISCUSSION}

Based on the results of descriptive analysis of the frequency of research data on strength and endurance in new students of the University of Muhammadiyah Surakarta, the discussion of research results can be described as follows:

a. Based on the results of the Strength test of new sports education students at the Muhammadiyah University of Surakarta, out of a total of 141 samples studied with push-up tests and sit-ups of moderate categories. This is obtained from the results of push-up tests with the most categories in the moderate category as many as 
52 students $(36.88 \%)$ and sit-up tests with the most categories in the moderate category as many as 51 students $(36.17 \%)$. Thus the strength of new students POR UMS medium category.

b. Based on the results of the Endurance test of new sports education students of the University of Muhammadiyah Surakarta, out of a total of 141 samples studied with good category MFT tests. This is obtained from the results of the MFT test with the most categories in the good category as many as 49 students (34.75\%). Thus the endurance of new students POR UMS good category.

\section{CONCLUSION}

Based on the results of research that has been obtained, it can be concluded that the strength of new students POR UMS as a whole is a moderate category obtained from push-up tests with a percentage of $36.88 \%$ and sit-up tests with a percentage of $36.17 \%$. As for the endurance of new students, the POR UMS category is good with a percentage of $34.75 \%$.

\section{ACKNOWLEDGEMENT}

Thanks to the Muhammadiyah University of Surakarta which has facilitated and provided researchers with the opportunity to conduct research.

\section{REFERENCES}

Azwar, S. (2011). Reliabilitas dan Validitas. Pustaka Pelajar.

Fachrezzy, F., Jariono, G., Maslikah, U., \& Nugroho, H. (2020). Functional
Exercise Model for Weight Loss in Sports Science Faculty Students. 159165.

Hermawan, I., Indrawira, H., Maslikah, U., Jariono, G., \& Nugroho, H. (2021). Pelatihan dan Penyusunan Latihan Fisik Pada Anggota Komando Strategis Angkatan Darat ( KOSTRAD ). 1(1), 27-34. https://doi.org/10.25008/altifani.v1i1. 115

Hermawan, I., Maslikah, U., Masyhur, M., \& Jariono, G. (2020). Pelatihan Kondisi Fisik Pelatih Cabang Olahraga Kota Depok Jawa Barat Dalam Menghadapi Persiapan Porprov 2022. Prosiding Seminar Nasional Pengabdian Kepada Masyarakat 2020 (SNPPM-2020), 1(1), 371-380. http://journal.unj.ac.id/unj/index.php/ snppm

Jariono, G., Nugroho, H., \& Hermawan, I. (2001). The Effect of Circuit Learning on Improving The Physical Fitness of Elementary School Students. International Journal of Educational Research \& Social Sciences, 2(2), 5968.

https://doi.org/https://doi.org/10.5160 1/ijersc.v2i1.22

Jariono, G., Nursubekti, N., Indarto, P., Hendarto, S., Nugroho, H., \& Fachrezy, F. (2020). Analisis kondisi fisik menggunakan software Kinovea pada atlet taekwondo Dojang Mahameru Surakarta. Transformasi: Jurnal Pengabdian Masyarakat. https://doi.org/10.20414/transformasi .v16i2.2635

Jariono, G., \& Subekti, N. (2020). Sports Motivation Survey And Physical Activity Students Of Sports Education Teacher Training And Education Faculty FKIP Muhammadiyah University Surakarta. Kinestetik: Jurnal Ilmiah Pendidikan Jasmani. https://doi.org/10.33369/jk.v4i2.1244 
9

Mutohir, Toho Cholik Dan Ali Maksum, 2007. Sport Development Index, Alternatif Baru Mengukur Kemajuan Pembangunan Bidang Keolahragaan, Konsep, Metodologi Dan Aplikasi, Jakarta: Indeks

Nugroho, H., Gontara, S. Y., Angga, P. D., Jariono, G., \& Maghribi, I. L. (2021). Quality Of Physical Condition Of Youth Pencak Silat Athletes Reviewed From Speed, Power. Kinestetik : Jurnal Ilmiah Pendidikan Jasmani, 5(1), 154-162. https://ejournal.unib.ac.id/index.php/ kinestetik/article/view/14376

Riduwan. (2019). Belajar Mudah Penelitian untuk Guru-Karyawan dan Peneliti Pemula (11th ed.). Alfabeta.

Ridwan dan Akdon, (2013). Rumus dan Data dalam Analisis Statistika, Untuk Administrasi Pendidikan, Bisnis, Pemerintahan, Sosial, Kebijkan, Ekonomi, Hukum, Manajemen dan Kesehatan. Bandung: Alfabeta

Rivai, Veithzal dan Murni, Sylviana, (2009). Education Management, Analisis Teori dan Praktik, Jakarta: RajaGrafindo Persada

Slameto (2003). Belajar dan Faktor-faktor yang mempengaruhinya. Jakarta: Rineka Cipta.

Slathia, R., Singh, H., \& Dar, H.A. (2015) Motivation among male and female cricket players of Jammu division: A comparative study. International Journal in Physical \&Applied Science, 2(4), 53-56

Sudijono, A. (2012). Pengantar Statistik Pendidikan. Raja Grafindo Persada.

Sugiyono, (2007) Metode Penelitian Kuantitatif Kualitatif dan R\&D. Bandung: Alfabeta

Suryabrata, 2011. Psikologi Pendidikan (Jakarta: Raja Grafondo Persada

Vilhjalmsson, R., \& Kristjansdottir, G. (2003). Gender differences in physical activity in older children and adolescents: The central role of organized sport. 